\title{
Mechanisms of Mobility in a Capitalist Culture: The Localisation of the Eye of (Global) Authority in the Novel and the Film of Jhumpa Lahiri's The Namesake
}

\author{
*MOUSSA POURYA ASL \\ NURUL FARHANA LOW ABDULLAH \\ MD SALLEH YAAPAR \\ School of Humanities, Universiti Sains Malaysia, \\ 11800 USM Pulau Pinang, Malaysia \\ *Corresponding author: ms_pourya@yahoo.com
}

Published online: 30 December 2016

To cite this article: Moussa Pourya Asl, Nurul Farhana Low Abdullah and Md Salleh Yaapar. 2016. Mechanisms of mobility in a capitalist culture: The localisation of the eye of (global) authority in the novel and the film of Jhumpa Lahiri's "The Namesake". KEMANUSIAAN the Asian Journal of Humanities 23(Supp. 2): 137-159, https://doi.org/10.21315/kajh2016.23.s2.8

To link to this article: https://doi.org/10.21315/kajh2016.23.s2.8

\begin{abstract}
This article examines the modes of objectification of a collective subject described as "Indian American", through the panoptic technologies of literature and cinema as utilised in the United States (US) in the aftermath of 9/11. Following the 2003 publication of the novel by Jhumpa Lahiri, The Namesake, Fox Searchlight Pictures released Mira Nair's cinematic adaptation in 2007. Published in the aftermath of the $9 / 11$ event in the US, the story spans over three decades, telling of the diasporic experiences of a middle-class family of a minority culture, the Gangulis, from their immigration in the 1960s-which historically coincided with the rise of two contrasting social phenomena, Neoliberalism and the Oriental Other - to their present assimilated status into the mainstream American culture. We argue that the literary and cinematographic narratives of The Namesake are employed by the hegemonic state power to offer an antidote to the chronic insecurities unleashed by notions of both Neoliberalism and the Oriental Other. The study outlines the panoptic dimensions of both narratives and unpacks the way their visual, narrative and "characterological architectonics" correspond with what Michel Foucault calls "the carceral mechanisms of power". Novel and film thus act together to instantiate in the public the ideological interests of the capital which, in turn, mobilises the apparatus itself, doing so through narrative techniques that conscript the public into a unified scopic regime. In the diasporic world of The Namesake, as the article concludes, the individual difference is associated with social deviance, in a way that in society, the local subject and its individuality become a signifier of
\end{abstract}


guilt, whereas, assimilation into global cultural pluralism is made synonymous with conformity and normativity.

Keywords and phrases: Panopticon, minority culture, hegemon, the Oriental Other, Neoliberalism

\section{Introduction}

Mira Nair is one of the leading Indian diasporic filmmakers in America whose work is claimed to occupy a prominent place in the cinema of hybrid. As a primarily documentary filmmaker, her films such as India Cabaret (1985, dealing with the exploitation of female strippers in Bombay) and Children of a Desired Sex (1987, dealing with the abortion of female foetuses in a society that favours male offspring) explore Indian cultural tradition. In 2006, Nair directed a cinematographic representation of Jhumpa Lahiri's best-selling novel with the same name, The Namesake (2003). As a diasporic novel, the narrative chronicles three generations of the Ganguli family, beginning with the arranged marriage of Ashoke and Ashima, their immigration to the United States (US) in the 1960s, proceeding with their life in America and their raising their two children, Gogol and Sonali and ending with Ashoke's death and Ashima's traveling back to India. As the title reveals, the narrative mostly centres around the rebellious protagonist, Gogol Ganguli's namesake which is taken from a so-called eccentric Russian author and is thus a constant reminder of the family's and in particular his own racial, historical and cultural difference. Gogol's name thus represents the family's "tastes, preferences and customs, a way of being that marks how foreign they are in this world [i.e., America]" (Mani 2012, 78). The story then goes on with Gogols' rejection of his namesake and changing his name to Nikhil with the hope of assimilation into dominant culture and a better integration with his American peers.

Both the novel and the film have received positive reviews/acclaims from mainstream readers and critics, ${ }^{1}$ a very ready acceptance that is believed to be in stark contrast with previous South Asian American writers and intellectuals including Ved Mehta, Bharati Mukhejee or Meena Alexander, among others. The hyper-visibility of them is even more exposed by Lahiri's recently winning the 2014 American National Medal of Arts and Humanities for her "truthful" representations of minority culture experience. Such meteoric success of both intellectuals and in particular Lahiri's, has already raised new questions regarding their naming and postcoloniality (Cheung and Dhingra 2012, 30).

In its engagement with these works, the purpose of this essay is two-fold. First we attempt to problematise the so-called truthful representations of experimental 
diasporan literature and film. In doing so, we charge both representations with not being neutral reflections, with being necessarily embodied, located and contingent and thus with being made from an interested point of view. Here, we argue that since both the novelist and the filmmaker are forced to use the dominant regimes of knowledge production, their self-expression or their role as being true informants of the minority culture, is inevitably impossible within the hegemonic discourse.

Second, this essay explores the ways literature and cinema, as examples of Foucauldian social apparatuses (dispositifs), act to instantiate in the public the ideological interests of the capital that mobilises the apparatus itself, doing so through constructing a kind of panoptic machine that underpins the "modes of social regulation and control" that Foucault $(1995,235)$ refers to as "disciplinary" technologies.

We argue that both literature and cinema are not only artistic genres but also socio-politico-economic institutions in which the readers and spectators are conscripted into a literary/cinematic illusion, so that their gaze on the texts, the gaze of the characters within the texts and the gaze of the narrator/camera (as the surrogate of the author/auteur) are organised into a unified scopic regime that is in accordance with the institution of these cultural products and their ideological investments. In this manner, both literature and cinema might be considered as apparatuses that are utilised by mainstream hegemonic culture to establish ideologised images of power and plenitude within the culture of the minority.

Regarding the selected versions of The Namesake, both works are categorised as postcolonial and hence are expected to gaze at the gaze. Both offer the advantage of showing the process of gazing, subjects looking and being looked at, the affects and effects of those gazing subjects and the way that their literary/cinematic gaze formulates and structures the discourse they are located in. The present essay aims at identifying the political, cultural and affective consequences of both cultural products and highlighting their particular enunciations of the gaze. By situating the narrative in its historico-political context, this study thus seeks to: First, evince the way the narrative's exercise of visual operations rigidly corresponds with those of the Panopticon and second, foreground the way its panopticism makes the story a record of and a participant in the social, sexual and political "paranoia" prevailing the American propaganda of it being the land of freedom. Unless one appreciates the phenomena of Oriental Other and Neoliberalism, one may not be able to comprehend the formation of minority culture within the so-called multicultural discourse of America, nor could one understand the migrants' response to these socio-cultural circumstances. 


\section{Socio-historical Background}

Many modern multicultural societies have developed from long and varied periods of immigration. One such modern state that is usually characterised by its wide variety of cultures and ethnicities and stands as "the signifier of migration itself" (Hall 2007, 137) is the United States of America. ${ }^{2}$ During the second half of the 20th century, particularly the 1960s and 1970s, a period of time that coincided with the end of colonisation across Asia and Africa, the country hosted a large number of immigrants from different ethnicities - including South Asian Indians - around the world.

Emigration of Indians or people of Indian origin to the United States also dates back to early nineteenth century. ${ }^{3}$ Like most immigrants, the Indian immigrant's decision to migrate to the United States was "to take opportunity of the chance for a better life financially and socially" (Hilaire 2006, 51). The 1924 Immigration Act, however, prohibited entry to South Asian immigrants, indicating a race- and class-based politics, because according to the act, "in the opinion of the Government of the United States ... [the immigrants' entry] endanger[ed] the good order of certain localities within the territory thereof" (Okihiro 2014, 4). ${ }^{4}$ An important turning point occurred during the 1960s, when the 1965 Immigration $\mathrm{Act}^{5}$ opened the floodgates for Indian immigrants, in particular for those with professional qualifications, adding to the multicultural nature of the US.

Ironically, the opening of the floodgates for Indian immigrants in the middle of the 20th century, which was primarily enacted to abolish the Orientalist Exclusion Act of early 20th century, coincided with the emergence of a yet extremer notion of the Oriental Other in the United States. Being brown turned into a racial formation and in the tumult of the Cold War, it was associated with the Communist threat. This type of racialisation was not new; rather, "it was a recuperation of much older and different colonial legacies brought back to serve new purposes. The Oriental Other has been an aspect of Euro-American culture for over two hundred years" and, in the US, the "Oriental" by the middle of the 20th century referred to those who were not "white" (Grewal 2003, 546). ${ }^{6}$

The correlation between South Asian ethnicity and Communism not only led to the construction of new identities and new racial and gendered hierarchies, it also permitted the hegemonic state power to establish and perpetuate disciplinary mechanisms to detect any forms of irregularity that were considered to be a "danger" or "risk" to the security of the nation state. ${ }^{7}$ Eventually, certain kinds of bodies, which were "identified as inclined to commit violence or having tendencies of violence essential to them", were incarcerated and criminalised. 
This included "large numbers of male migrants and immigrants from countries as diverse as Pakistan, India, Saudi Arabia, Kuwait, Jordan, Yemen and a number of other countries" (ibid., 547). Though this type of orientalism was primarily based on visible features - facial characteristics such as beards, dark eyes and turbansthe disciplinary technologies were expanded to scrutinise and police even private behaviours which could be considered as socially abnormal, such as anything which might cause the destabilisation of the family unit, including the individuals' sexual inclinations (Hurley 1997, 52). These normative practices pervaded all of society, permeating even the micro-politics of minority culture, through surveillance and unavoidably led to the restriction of individuality. ${ }^{8}$ This regulating phenomena was advocated by expressions of "cultural anxiety" in the guise of a paranoiac attempt to remove any potential danger to national security by simply regulating the other's subjectivity. Such regulative disciplinary technologies of American nationalism, recuperated in the mid-20th century, were even reinforced in the US after the terrorist attacks of 9/11, making race and gender, once again, the regulative apparatuses of the powerful state. The attacks provided ideal conditions for the growth of this anxiety. The Americans were presented with "an external threat emanating from people who espoused beliefs that were highly dissonant with American ideals" (Arnold 2008, 162). The threat was analogous with the one the global communism had posed to the American way of life in the second half of 20th century and in like manner "fuelled fear and paranoia about conspiracy in the nation's midst" (ibid., 162). Since the public was concerned that "ordinary" Americans might be engaged in such "treachery", attempts were made to identify hidden enemies. The public, according to Arnold, "were leery of anyone who appeared 'foreign' ... [They] remained apprehensive, resigning themselves to a new era of color-coded terrorism alerts and increasingly pervasive security measures in everyday life" (ibid., 162). Obviously, the post-9/11 rhetoric prepared the ground for further demonisation ${ }^{9}$ of racial and gendered minorities, subjecting them to forms of regulation and self-regulation by means of the "'law and order' apparatus of policing, surveillance and incarceration of adults (mostly non-white) and children" (Grewal 2003, 541).

Going back to the second half of the 20th century, the 1970s also witnessed the emergence of another social phenomenon that many scholars refer to as neoliberalism, with its prevailing rhetoric that the US is individualistic and renounces any form of oppression (Ong 2006; Ferguson and Hong 2012; McWhorter 2013). Neoliberal rhetoric, according to McWhorter (2013, 62), "is overwhelmingly individualistic. Individuals must assume the risks and the costs of pursuing their goals ... [and] suffer the consequences of their mistakes". Under the neoliberal governmentality, the subjects assume responsibility for their own security, well-being and quality of life and thereby disengage the state "as free individuals to confront globalized insecurities" (Ong 2006, 501). In doing so, this 
dominating discourse of individualism exonerates the state from any kind of privileging or oppressing groups. In other words, the neoliberal state appears to be a less regulatory one that typically intervenes less in both the public and private lives of its citizens and values instead "self-governing and self-enterprise" (Kimmel and Llewellyn 2012, 1087). Ong $(2006,502)$ associates the neoliberal discourse of American culture-with its focus on the self-governing of the citizens - with the construction of a "civic society" or the formulation of "national solidarity" and affirms that within this discourse, those citizens "who cannot scale the skills ladder or measure up to the norms of self-governing are increasingly marginalized as deviant or subjects who threaten the security" of the state. At this point, the subjectivity of individuals, once again, ironically becomes a part of the apparatus of the hegemonic power and thus is the rise of neoliberalism linked to the emergence of "a new political entity and object of love, a new article called minority culture", which by the arrival of immigrants in the period after World War II provided the hegemon with "the building blocks for a new way to regulate" (Ferguson and Hong 2012, 1058).

To this contrasting situation - of an orientalist and racist denial of individualism on the one hand and a neoliberal valorisation of individualism on the othermigrants could respond in two ways. One way was to protect themselves against racism by displaying the sign of allegiance to the multicultural American nation. In such cases, those who looked different "had to signal their allegiance to 'America' and to being 'American' by the same logic of visibility that marked them as racially un-American, in order to avoid becoming victims of racist violence," involving their demonstrable loyalty and national allegiance to "white, masculinity and heterosexual Americanness" (Grewal 2003, 548-550). But this did not necessarily mean that Indian immigrants could not act at all or they were entirely trapped and absolutely immobilised, meaning that they were not necessarily confined entirely to actions and behaviour prescribed by the rightwing guardians of American nationhood.

The racialised subjects had another option, one which, in the first place, necessitated their recognition of the immobilising political and socio-economic system operating against them and then their organising themselves against that system. Migrants could thus choose to struggle against the orientalist paranoia by taking effective action to rearrange social structures and practices and consequently alter their situation. Such a movement, however, would involve a high risk of pain and loss, because, as Frye observes,

If we comply, we signal our docility and our acquiescence in our situation. We need not, then, be taken note of. We acquiesce in being made invisible, in our occupying no space. We participate 
in our own erasure. On the other hand, anything but the sunniest countenance exposes us to being perceived as mean, bitter, angry or dangerous. This means, at the least, that we may be found "difficult" or unpleasant to work with, which is enough to cost one one's livelihood; at worst, being seen as mean, bitter, angry or dangerous ... One can only choose to risk one's preferred form and rate of annihilation [italics my emphasis] (quoted in Hale 1996, 104).

Since Indian diasporas in America have always been unable to be fully accepted by the "host society", they have long begun to foster "feelings of alienation or exclusion or superiority or other kind[s] of difference" (Vertovec 1997, 4). As Jayaram N. notes, the "racial and cultural differences and the difficulties of integration or assimilation in the host society, pave the way for longing and excessive concern for the motherland" (quoted in Pande 2012, 97). Such conditions have led diasporas to maintain a variety of explicit and implicit ties with their homelands and thus, to not only develop a dream of return, but also develop a feeling of resistance to the present political and economic situation, to stand against the "structured prejudices and discrimination" (ibid., 98) which they encounter on a day-to-day basis.

Scholars like Cohen $(1995,10)$ believe that being aware of their precarious situation, members of a diaspora are propelled to "advance legal and civic causes and to be active in human rights and social justice issues". Subsequently, in recent years, intellectuals and activists from these populations have increasingly begun to stand against the discrimination imposed by the mainstream culture. With their growing connectivity to their homeland, the people of Indian origin have attempted to reinvent and reassert their Indian identity by trying to translate and reformulate the cultural traditions within the diaspora and by giving voice to the subaltern experience. As Schiller, Basch and Blanc-Szanton explain:

Within their complex web of social relations, transmigrants draw upon and create fluid and multiple identities grounded both in their society of origin and in the host societies. While some migrants identify more with one society than the other, the majority seem to maintain several identities that link them simultaneously to more than one nation. By maintaining many different racial, national and ethnic identities, transmigrants are able to express their resistance to the global political and economic situations that engulf them, even as they accommodate themselves to living conditions marked by vulnerability and insecurity (quoted in Vertovec 1997, 9-10). 
The post-1965 immigrants, as we have noted, brought highly educated professionals qualified in various fields of expertise, such as science, technology and the social sciences. Many of these highly educated immigrants, particularly the ethnic writers, were also looked upon as experts on or "informants" about Indian culture (Aubeeluck 2006, 5). Two of the most celebrated intellectuals in the past fifteen years, in the realm of South Asian American literature and cinema, are Jhumpa Lahiri (b. 1967) and Mira Nair (b. 1957), the former a young writer who has published mainly in the West and heralds "a new era" and "season of discovery" for Indian literature in English (Bhalla 2008, 181) and the latter an Indian-born, New York-based director who has "repeatedly enacted tales of culture clash in her films but never with quite as much warmth and thoughtfulness as she brings to The Namesake" (Lim 2007). This essay in a way aims to focus on Lahiri's literary and Nair's similar cinematic response to the racialisation and gendering of a collective subject described as the Indian diaspora, in the US in the post-1960s era.

\section{Native Informants or Agents of Exploitation?}

Indian diasporic intellectuals, who have persistently striven to provide a voice for the subaltern, have ironically been censured for their inaccurate representations of Indian culture and for their complicity in the dissemination of the pre-existing hierarchies of the dominant culture. Although these intellectuals are perceived as having enriched the lives of the Indian community in the United States by fighting against discrimination, they are looked upon as outsiders in India, being accused of writing from a remote, culturally compromised position in the West. As an Indian immigrant writer and concerning her diasporic identity, Jhumpa Lahiri has likewise been the subject of much debate and criticism. Many critics have commended her for moving away "from previous generations' narratives of assimilation or representations of ghettoized ethnic existences" (Alfonso-Forero 2011, 26). These critics argue that Lahiri's writing decentralises and deconstructs previously established stereotypes, established by either the West or by the Indians themselves and offers a balanced, universal representation of the Indian immigrant (Aubeeluck 2006; Alfonso-Forero 2011; Dhingra 2012). On the other hand, some scholars (Bhalla 2008; Mani 2012; Asl, Hull and Abdullah 2016) have examined Lahiri's works in the light of Orientalising discourses and postcolonial exoticism and have criticised her works for not being postcolonial at all. They point to Lahiri's highly celebrated representations of Indian culture to assert that her Indian characters are widely acceptable in America because of their exoticism.

In a similar way, the film version of The Namesake has been the target of much critical debate. Nagajothi $(2013,8)$, for instance, acknowledges Nair's "fidelity discourse" and her ability in unveiling "the intricate layers of the novel into visual 
vibrant shows with authentic locales, breathing characters". Mohan and Arora $(2013,40)$ take a step further by proposing that Nair sidesteps the original work's "emphasis on assimilation, offering a point of view suspicious of the sense of security and upward mobility promised by integration into the nation". On the contrary, Das $(2013,4)$ points to scenes like picturing the poor people in Calcutta to argue that the movie "is mainly made for Anglophone audiences as is the novel". To this, one may add the deletion of racial abuse of Bengali Indians by Graham, an American character in the novel, that underscores "there is a kind of invisible manipulation by [the] filmmaker during translation" (ibid., 4). Bose (2010, 163-164) contributes to a better understanding of this manipulation by convincingly highlighting the relation between cinema and apparatus. According to him, in Indian diasporic films, the camera, utilised to show diasporic experience, may identify particular moments in time and space and reproduce diasporic "realities in a particular mode that then offers entirely new formations of the subject". This is particularly obvious, as Bose asserts, in the emergence of "the Great American Dream of freedom and individuality ... as a sustained trope in South Asian diasporic cinema" (ibid., 168).

Within this context, speaking of postcolonial America and the resistant attitude of immigrant women intellectuals, anticipated by anticapitalist transnational feminists like Mohanty (1984; 2014), the following paragraphs can be followed to elaborate on the problem of a perceived degree of compromise and complicity in the Indian diasporic writer and state it more specifically in the context of the subjects' own localisation and internalisation of the power hierarchies.

Bill Ashcroft, Gareth Griffiths and Helen Tiffin's The Empire Writes Back (2003), one of the earliest theoretical discussions of postcolonial literature, makes a frequently cited claim regarding the extent to which the United States can be considered a postcolonial society. They argue that the United States is postcolonial to the extent that its culture, specifically its literature, was the first independent national literature to emerge in response to a struggle for liberation from an imperial power. Since the 1965 immigration legislation, which enabled the United States to experience mass immigration from non-European countries, it has striven to define itself as the world's first independent, anti-colonial state (Singh and Schmidt 2000, 5) and "multicultural" nation (Grewal 2003; 2005). However, taking advantage of the uneven distribution of wealth and power left behind after the departure of the British, the US spread "the promise of democratic citizenship and belonging through consumer practices as well as disciplinary technologies" (Grewal 2005, 2) and in the process created diverse, transnational subjects. That the United States is able to become a neoliberal imperialist power and remain a hegemon precisely because of the colonialism that preceded it in countries such as India, has been convincingly argued by 
scholars like Singh and Schmidt (2000), Spivak (1999), Grewal (2005) and Alfonso-Forero (2011).

Grewal (2003, 539), for instance, examines the recent racialisation and gendering of a collective subject described as "Middle Eastern or Muslim" in the US. This new form of category, according to her, became visible through the operations of disciplinary power and through the binary of freedom-incarceration, securitydanger. Security and freedom can only be achieved by the incarceration of "riskproducing" and dangerous bodies. In this regard, "race and gender become modes of knowledge that produce the figures of danger and risk through technologies of surveillance, visibility and, most importantly, self-regulation". As a result, a new form of governmentality, called "multiculturalism", appeared that is both regulative and productive of American nationalism and transnationalism (ibid., 535). Grewal elaborates that:

Multiculturalism has become one such technology in the US as a state project, produced through the census, laws, regulations of immigration and those "protecting" minorities to create racialised and gendered subjects who see themselves as "American" at some points and as different kinds of Americans at other times and places (ibid., 538).

In any case, the gendered and racial minorities turn into a potential danger to both themselves and to the host country and thus "have to be subject to forms of regulation and self-regulation" (ibid., 539). In a similar way, Alfonso-Forero examines the manner in which mainstream American culture, in addition to certain nation-state policies, allows the US to take on a colonising role in regard to its immigrants. This form of internal colonisation involves pressuring immigrants to become more "American", to speak English only and aspire to the type of economic success that can be difficult for first-generation immigrants to achieve in an increasingly corporate capitalist economy (Alfonso-Forero 2011). In addition, immigrants from postcolonial nations often reproduce class and gender relations that emerged in response to colonial and postcolonial conditions in their countries of origin, in their new American environment.

The possibility of America's shift from colony to hegemonic superpower has three consequences. First, the reality of violence and oppression brought about by such a change. Second, the construction of various dichotomies that come into play as foils for each other, such as civilised-savage, first world-third world, dominator-dominated, invader-conquered, with both cultures encroaching on each other's territory and the impossibility of denying each other's absence or presence. Third, attempts to efface the new colonised culture. When the "first 
world" is set up in opposition to the "third world", logic dictates that the West is progressive, modern, enlightened, educated, innovative and civilised. This presumed superiority not only "reinforc[es] Western cultural imperialism" (without questioning the assumed power dynamic between the "first" and "third" worlds), but it also compels the liberal impulse of the West to assume the moral obligation to liberate the subjects from their "shared oppression" (Mohanty 1984, 337-352). In response to the constructed racial and gendered identities, the hyphenated subjects, "Rather than becoming hybrid subjects that incorporate one or two races or nationalisms ... are flexible and changing, moving from one subjectivity to another, not necessarily hybrid but flexible and contingent as well as able to co-exist with contradictory subject formations" (Grewal 2003, 538). The establishment of such hierarchies and the consequent attempts to revolt against them has informed almost all discussions relevant to ethnic American identity, including postcolonial female immigrants in the United States (AlfonsoForero 2011, 23).

While some critics confirm that it is the responsibility of the individuals within the group to decentralise the dominant power hierarchies in order to assert their individuality (Grewal 2003; McWhorter 2013), other scholars blame the immigrant writers for conforming to mainstream American culture and for perpetuating the pre-existing power relations. Spivak $(1999,357)$ declares that "the hyphenated Americans [...] might rethink themselves as possible agents of exploitation, not its victims". She calls Indian American writers "at best native informants for first world intellectuals interested in the voice of the Other" (Spivak 1988, 284) and later maintains that the idea of the ethnics speaking for themselves is a "somewhat dubious" one, (Spivak 1999, 40) or even an "impossible perspective" (ibid., 4).

As a Bengali Indian and ethnographer, Ganguly $(2001,37)$ confirms the problem by being sceptical over "the so-called accurate representations in postcolonial narratives". She investigates Indians living in New Jersey to argue that immigrant "informants" (to use Spivak's term) tend to "(mis)remember the past in sublated terms", so that the information considered to be authoritative by them can be contradictory (ibid., 106). Grewal takes issue with what she argues is the immigrant writer's reinscription of non-Western difference - especially in the way they represent non-Western women - and valorisation of Americanisation and American values. She asserts that a non-Western writer has a singular responsibility to refute stereotypes of women in the "third world" in order to avoid what she perceives is a cultural recolonisation of these women (Grewal 2005). 
That being said, even the commendation of Lahiri and/or Nair for their "precise, evocative and convincing" depiction of Indian immigrants by some (Western or American) critics ironically works against them, by inciting other critics to express doubt and suspicion over their credibility as a voice for the Asian or Indian diaspora. To this, one may add the warm reception and overwhelming success and popularity that Lahiri's novel and Nair's film have gained not in third-world India, but principally in the first world hegemonic culture of the United States. Spivak's concern over the possibility of the hyphenated subjects' being the agents of exploitation rather than its victims, is highlighted by the very recent remarks of the US President on Lahiri's fiction. While presenting the 2014 National Medals of Arts and Humanities to Lahiri, President Barack Obama stated that:

I always do good with writers and scientists. Those are my crew ... truth is such a rare thing, it is delightful to tell it ... and that's especially true in Washington. The men and women that we honour today, recipients of the National Medals for the Arts and the Humanities, are here not only because they've shared rare truths, often about their own experience, but because they've told rare truths about the common experiences that we have as Americans [italics my emphasis] (Obama 2015, paragraph 3).

\section{Individuality as a Social Deviance}

As it is already stated, this essay seeks to analyse the relation between literature/cinema and ideology and attempts to find the link between technology and social control. It was also mentioned that after the events of $9 / 11$, the US, as the hegemonic capitalist state power, utilised dominant representations of media to produce new discourses of American nationalism by constructing new racial and gendered formations (Grewal 2003). The emergence of this new discursive formation (i.e. the discourse of nationalism) gave rise to a new institutional form (e.g. prison/exile), a new knowledge form (i.e. ethnic studies) and new object of knowledge (i.e. Indian immigrants/diaspora).

The present study not only described this particular discursive formation, i.e. American nationalism, (through "archaeology") but also explicated how and why it came about. By doing so, it attempted to move beyond the discursive formation of American nationalism to a consideration of a collected subject described as Indian diaspora as the other form of knowledge that is formed and constituted by power-viz., non-discursive formations and the formation of subjects. It is to be reminded that "non-discursive formations are practices through which power is manifested in particular forms (e.g., the prison, the asylum, the hospital, etc.)" 
(Jun 2010, 146). Subjects (i.e. the Indian immigrants) in turn, are created through the process of being acted upon by non-discursive practices.

From a Foucauldian perspective, literature and cinema are both discursive and non-discursive formations: "a mode of knowledge manifested concretely at the level of individual [texts/] films and a mode of power manifested at the level of the [literary/] film industry" (ibid., 148). Though neither one is reducible either to its formal (i.e., discursive) or politico-economic (i.e., non-discursive) components, with respect to the discourse of American nationalism, there is no way to disentangle literary and cinematic productions from mainstream culture as they are appropriated by the dominant culture for its own ends. In other words, it proves to be a false claim that literature and cinema are produced as "'pure' artform or 'neutral' communication technology", rather, they are "particularly wellsuited as a medium to being appropriated and used for oppressive purposes" and are a perfect example of how hegemony naturalises dominant ideology and makes social constructions into established truths (ibid., 149-151). The question becomes: how, if at all, are literary and cinematic forms of The Namesake being appropriated and used in the contemporary American context and what does this say about experimental diaspora representations in America?

In his influential conceptualisation of the principles of social control and deviance, Foucault $(1995,28)$ describes a mode of social regulation and control as "disciplinary technologies": "the set of material elements and techniques that serve as weapons, relays, communication routes and supports for the power and knowledge relations that invest human bodies and subjugate them by turning them into object of knowledge". His model for such employment of power hierarchies is what he borrows from Jeremy Bentham: the Panopticon. Bentham's panoptic design is a circular architectural structure in which the prisoners are monitored by an omnipresent observer. This "all-seeing place" is a type of prison, also known as the "Inspection House", whose construction "enables an observer to watch all the prisoners without their knowledge" (Jespersen et al. 2007, 110). By making the inmates assume that they are always being watched by the guards, the deployment of the principle of gaze and surveillance in this utopian prison ultimately brings about a controlling, dominating and normalising behaviour. Foucault $(1995,201)$ regards this as a strong point of the Panopticon that is able to "to induce in the inmate a state of conscious and permanent visibility that assures the automatic functioning of power...a power relation independent of the person who exercises it;...the inmates should be caught up in a power situation of which they are themselves the bearers". Such disciplinary technologies, Foucault asserts, lead the society to act as a self-monitoring apparatus, with subjects assuming that "the gaze is alert everywhere" and that "thousands of eyes [are] posted everywhere, mobile attention [is] ever on the alert" (ibid., 214). The constant threat of the invisible observer and the consequent feeling of being 
continuously monitored generates a psychological state in the inmates to control their behaviour and be their own supervisor.

We propose that Lahiri's fiction displays a world at large where something like such a maximised Panopticon has been put into effect. (We get a hint of this in Kaushik's occupation: he is a world travelling journalist whose job is to record and domesticate alien experience by bringing it between the glossy covers of the kind of magazine that sits comfortably in American living rooms.) The characters exist comfortably within a belief system whose behavioural economy is safely regulated and thus predictable and secure. This dichotomous behavioural economy governs almost all major characters like Ashoke, Gogol and Moushumi. Some characters, for example, display a discontinuity between an appearance of nonconformity and an actuality that is essentially conformist. In some characters we can also find a guise of eccentricity that belies a deeper embrace of the familiar, the expected, the ordinary, the American.

When one turns to the historico-political milieu in which The Namesake is produced and situated, i.e. the contemporary accounts of America since mid-20th century onwards, it becomes clear that the country's "dynamic social and economic expansion was bringing about a dangerous cultural homogenization, making the country ... uniform and standardized" (Hurley 1997, 40). The need for homogeneity was due to an apparent release of "the centrifugal energies" that were brought upon by the aforementioned industrial, economical and cultural expansion. Deleuze interprets this as an extension and intensification of capitalism whereby cultural homogenisation becomes the moral standard, desires controlled and possibilities of resistance strongly diminished. Yet, it is to be noted that for Foucault, power is not and cannot be centralised in the form of a single coercive apparatus such as "capitalism". It exists not only at the macrolevel of society (e.g., in ideologies, governments, etc.) but also at the micro-level of subjects (as in disciplinary power).

Cultural homogenisation, however, necessarily involves the construction of societal stereotypes which can be overturned through practices of individualism. This individualism is a return to an older stereotype, "that of more traditional forms of social behaviour. And this conformity allows what had been presented as a stereotype to be re-presented as individuality at its most ominous and unacceptable - as deviance" (ibid., 42). In The Namesake, the separation of an individual from the stereotypical hyphenated Americans is crucial for the society's identification of its "abnormalities", its threatening Others: as the title of the novel reveals, the object of social scrutiny is no longer the "Indian", one of a number of immigrant "types" (Ashoke, Shukumar, Kaushik, to name a few), but the specific individual Gogol Ganguli, whose first name is taken from the 
Russian writer, Nikolai Gogol. By making the transition into individual identity, Gogol is thus doubly alienated. His is a name with difference, that rather than throwing him into a community of fixed stereotypes, singles him out as one individual among others, leaving an "expression of benign amazement" on the face of his school teachers and provides him with a ring of foreignness and a tinge of national threat in the discourse of American nationalism (and the foreigners potential threat since the Cold War period), that sets him apart even from the partially normalised "Indian" names. His individuality, indicated by his doubly foreign name, thus, has to be familiarised and subsumed into a unity, a community that must fit the needs of contemporary government. In this regard, one ideal mechanism for the exercise of furtive power in which social deviance could be controlled with minimum force is the Panopticon that Foucault "felt could also work with similar effectiveness in all other organization which bring so many people together such as factories, hospitals and even schools" (Mungwini 2012, 344). As a regulatory mechanism, Gogol's school creates a panoptic social landscape that induces in him a feeling of permanent visibility and a state of consciousness about his being direct subject of "the normalising judgment" of the school teacher, Mr. Lawson and his classmates. The sight of his name, "printed in capital letters on the crinkly page upsets him viscerally. It's as though the name were a particularly unflattering snapshot of himself that makes him want to say in his defence, 'That's not really me,"' Gogol complains (Lahiri 2003, 89). Through the ever-present gaze of his classmates, Gogol perfects mechanism of judging himself according to what is prescribed as normality in the then American society and attempts to constitute himself as a normal citizen or member of the class. The attempt indicates the extent to which he has been the object of scrutiny not just as "a student", one of a number of other classmate "types", but the specific person Gogol. As the class goes on, he "wants to excuse himself, to raise his hand and take a trip to the lavatory, but at the same time he wants to draw as little attention to himself as possible. And so he sits, avoiding eye contact with any of his classmates and pages through the book" (ibid., 89).

Gogol's active involvement in the process of self-creation in this scene is after all built on the cultural assumption that certain actions are not appropriate for a desirable constitution of the individual. The normalising power of society is still much more reinforced when he hears the teacher reading aloud details of Nikolai Gogol's homosexual inclinations and his subsequent affliction with depression and starvation. Nikolai Gogol, Mr. Lawson reads, is

Not your ordinary guy ... "He is celebrated today as one of Russia's most brilliant writers. But during his life he was understood by no one, least of all himself. One might say he typified the phrase 'eccentric genius'. Gogol's life, in a nutshell, was a steady decline into madness. The writer Ivan Turgenev 
described him as an intelligent, queer and sickly creature. He was reputed to be a hypochondriac and a deeply paranoid, frustrated man. He was, in addition, by all accounts, morbidly melancholic, given to fits of severe depression. He had trouble making friends. He never married, fathered no children. It's commonly believed he died a virgin" (ibid., 91).

Through the teacher's judgmental comments, the axis of normality and abnormality around which disciplinary norms revolve expresses itself in the distinction between the "ordinary" and the "eccentric", the "mad", the "queer", the "hypochondriac", the "paranoid", the "melancholic" and finally and more importantly, the "homosexual". The sexual and psychological deviance of Nikolai Gogol permits Mr. Lawson to transform him into an Other of nearly monstrous perceptions - the image of reviving him on the day before his death while seven leeches were affixed to his nose, making this monstrousness nearly literal. Seeing the two poles of these norms and realising the constant threat of the invisible, disapproving gaze of the judges of normality, Mr. Lawson and the classmates, in particular and the "people", in general, Gogol subjects himself to selfexamination and self-regulation. Looking at his classmates, he wonders why "his parents have never told him any of this" and "feels betrayed" and ashamed. The sense of shame "originates in awareness of eyes of the outside world and is directed in toward the self. One feels shame when an improper action or failing is revealed publicly or to certain authorities or peers; it is a feeling especially connected with the group and is clearly associated with the fear of ridicule by others" (Liszka 1999, 15). In the case of the film, Nair's depiction of the scene is even more elaborate and revealing. Whereas in the novel, the gaze of Gogol's American peers is subtle-rather cast on an American girl named Emily Gardener for her rumoured anorexia than Gogol himself - and their remarks more general-"Gross ... why would someone want to do that to himself?", as someone said from the back of the classroom when the teacher was explaining Gogol's suicidal starvation (Lahiri 2003, 91) - the ridiculing gaze and contemptuous remarks of his classmates in the movie version are more explicit and more brusque. Throughout his adolescence, Gogol thus "struggles with the burden of distinguishing his experience from the experience of his namesake" and in order to meet the standards, social rules and expectations of the American society, he denies "not only his relationship to the Russian writer's homosexuality and depression, but also to the time of his father's life in India" (Mani 2012, 81).

In The Namesake, Moushumi undergoes a nearly similar transformation and becomes, much like Gogol, literally monstrous when, through her illegitimate affairs with Dimitri, she attempts to move from stereotype to individual. For if, on the one hand, there is a kind of stereotypical Indian woman, Ashima or her own mother spirituality in Moushumi, there is, on the other, something 
rebellious, centrifugal and Helenian betrayal in her married life. In this regard, "woman and monster alike are shown as radically Other and as embodiments of exhibitionism or spectacle" (Hurley 1997, 44). What makes the monster be different from the normal male is the former's sexual power. According to Linda Williams, the traumatised man sees the monster as remarkably like the way he sees the woman:

A biological freak with impossible and threatening appetites that suggest a frightening potency precisely where the normal male would perceive a lack .... It may very well be, then, that the power and potency of the monster....should not be interpreted as an eruption of the normally repressed animal sexuality of the civilized male...but as the feared power and potency of a different kind of sexuality (the monster as double for the woman) (quoted in Hurley 1997, 34).

In much the same way, it is the persistent image of Moushumi's connection to her former lover, Graham, that haunts Gogol and from time to time makes him "have a fleeting vision of himself, tragically abandoned" (Lahiri 2003, 237) and of Moushumi, increasingly detestably monstrous. Hence, these days, when Gogol looks at her, "the stale smell ... in her hair and on her fingertips and in the bedroom when she sits typing, slightly disgusts him" (ibid., 237).

Within this context, Moushumi's quest for liberation and individuality through her pursuing and illegitimately realising her sexual desires thus becomes a reflection of her threatening female sexual power and highlights the connection between the type of gender oppression exercised by the disciplinary technologies of the "neoliberal" discourse of late 20th century America that on the one hand advertised itself as a liberating force and on the other, propagated a "domestic" ideology that relegated woman to the state of a mere housewife.

\section{Conclusion}

The invisible surveillance of the Panopticon reveals a form of power that is dynamic, ubiquitous and diffuse. It operates only in the relations of those to whom it applies. It can be exerted on individual bodies (anatomo-power) or entire populations (bio-power). Minority Culture's adjacency to and otherness from the mainstream culture ensures that the privileged will note itself as other than the minority - the minority's absence from the dominant culture makes the American culture not-minor. Assimilation and attempts to homogenise hence reveal the fact that it is the mainstream culture in its entirety, in its common omnipresence, which is carceral. The disciplinary technologies of the hegemonic culture then in 
this way operates its regulating effects without even being noticed. This is elucidated by the fact that the world of diaspora in The Namesake is a place where one can easily note the controlling mechanisms of the hegemonic America in action, the immigrant characters' conduct of normativity and deviance that rules both the fictive and cinematic world can function unnoticeably, be seen as natural, not-minor and definitely as "normal".

The Namesake is therefore directly concerned with American culture's carceral machinery at work in it. The narrative reiterates Bentham's Panopticon idea: the model prison that signals the metamorphosis of liberalism into total scrutability. Such a dislocation of the gaze from a central stand to a marginal one, i.e. the invisibility of the Panopticon, is a visual literalisation of Foucalut's proposition of the Panopticon's "capillary" dissemination of power relations. As Foucault proffers, "The efficiency of power, its constraining force have, in a sense, passed over to the other side - to the side of its surface of application. He who is subjected to a field of visibility and who knows it, assumes responsibility for the constraints of power" (Foucault 1995, 202). It is also concluded that the absence of such a visible mechanism of Panopticon uncovers the extent to which its deployment of disciplinary control mechanisms has been effectively localised and internalised by the subjects. Within this disciplinary mechanism there exists a connection between normativity and visibility. In the diasporic world of The Namesake, the individual difference is associated with social deviance, in a way that in society, the local subject and its individuality become a signifier of guilt, whereas assimilation into global cultural pluralism is made synonymous with conformity and normativity.

\section{Notes}

1. For a review of some of the prestigious mainstream venues on Jhumpa Lahiri, see Dhingra, L. and Cheung, F., eds. 2012. Naming Jhumpa Lahiri: Canons and controversies. Plymouth, UK: Lexington Books.

2. The rich passage in which Hall describes the hybrid, diverse nature of America, calling it Terra Incognita [i.e. land which is undiscovered], is worth citing at some length: "The Third, 'New World' presence [i.e. America], ... is the juncture-point where the many cultural tributaries meet, the 'empty' land (the European colonisers emptied it) where strangers from every other part of the globe collided. None of the people who now occupy the islands - black, brown, white, African, European, American, Spanish, French, East Indian, Chinese, Portuguese, Jew, Dutch originally 'belonged' there. It is the space where creolisations and assimilations and syncretisms were negotiated. The New World ... has to be understood as the place of liny, continuous displacements: of the original pre-Columbian inhabitants, the Arawaks, Caribs and Amerindians, permanently displaced from their homelands and decimated; of other peoples displaced in different ways from Africa, Asia and Europe; the displacements of slavery, colonisation and conquest. It stands for the 
endless ways in which Caribbean people have been destined to 'migrate'; it is the signifier of migration itself - of travelling, voyaging and return as fate, as destiny" (Hall 2007, 136-137).

3. During the period 1820 to 1890 about 700 Indians came to America, rising only to 9,000 until 1917. But large number appeared much later, in particular during the second half of the 20th century.

4. The Immigrant Act of 1924, including the Oriental Exclusion Act, was basically enacted to preserve the ideal of US homogeneity and was the natural extension of racialist and increasingly restrictive immigration policies established earlier in 1917 (known as the Asiatic Barred Zone Act), when "the US Congress enacted the first widely restrictive immigration law". The restrictive policy was practiced due to "the uncertainty generated over national security during World War I [which] made it possible for Congress to pass this legislation" and paved the way for the 1924 Act. The new Act completely excluded immigrants from Asian lineage, in particular the South Asians, because based on a provision included in the Act, these people were categorised as aliens who by virtue of race (not being white) or nationality were ineligible for "Naturalization"-i.e. citizenship. For further elaboration on the provisions of the Act, refer to United States Department of State, Office of the Historian. The Immigration Act of 1924 (The Johnson-Reed act) (Data file). Retrieved from https://history.state.gov/milestones/19211936/immigration-act.

5. In 1965, a new act was proposed that finally abolished the 1924 immigration policies and restrictions. The new law gave a higher preference to persons with professional qualifications and thus replaced the long-practiced policy of "national origins quota system", with a "preference system". In spite of this, the new act still prohibited people who were unsoundly classified as "sexual deviants", e.g. the homosexuals.

6. Okihiro attempts to locate Asians within America's racial formation and show their closer affinity with Africans. He argues that "just like blacks", Asians have been marginalised to the periphery of race relocations in America. According to him, "Africans and Asians have both been relegated to the margins of American racial politics as 'nonwhites', but European-Americans have also differentiated Asians from Africans, mainly by prohibiting Asians from becoming naturalized and thereby denying them the rights of life, liberty and property" (Okihiro 2014, xi). In a parallel study on the struggles of West Indian families with similar racism in America, Hilaire points to the effects of such racial discrimination and argues that within this context, forcing the immigrants "to make decisions about their identification and internalized racism plays a significant role in their ambivalence about fully assimilating into American culture" (Hilaire 2006, 47). This internalised racism may lead to an internalisation of social shame-engendered by the acceptance and absorption of negative social stereotypes - and to self-hatred, accordingly (ibid., 54). In Dialogue and Diaspora, Nandy relates the internalisation of racism by Hindu immigrants to the emergence of a new Westernised kind of Hinduism in America and argues that the Hindus' selfconsciousness operates as a catalyst for their transformation and assimilation. According to her, "Out of feelings of inferiority, many Hindus have tried to re- 
define Hinduism according to the dominant Western concept of religion" (quoted in Vertovec 1997, 18).

7. In Transnational Locality: Diasporas and Indentured South Asians, Reddy identifies yet another reason Diasporas are often considered threatening to state security. She relates this perception to the immigrants' inhabiting a "transnational locality", arguing that "What is distinctive about Diasporas is that they are indigenized over time (Creolised, hybridised), but they retain a transnational identity that is associated with a perceived homeland (real or imagined) especially during periods of national or international uncertainty" (Reddy 2013, 1). Reddy explains that the perceived insecurity necessarily gives rise to policies that targets citizens and residents with diaspora connections.

8. For instance, it was only in the 1990 Immigration Act that the classification of homosexuals as "sexually deviants", "mentally defective" and implicitly as dangerous to nation-state, was eventually eliminated.

9. The socio-political milieu of post 9/11 appeared to be a return to the demonological traditions lying at the core of American history. In his study of the history of demonology in American politics, Rogin identifies three major moments: racial, class and ethnic and the cold war. Commenting on the racial moment, he says "'History begins for us with murder and enslavement, not with discovery', wrote William Carlos Williams. He was calling attention to the historical origins of the United States in violence against peoples of colour. The expropriation of Indian land and exploitation of black labour lie at the root not only of America's economic development, but of its political conflicts and cultural identity as well. A distinctive American political tradition, fearful of primitivism, disorder and conspiracy, developed in response to peoples of colour. That tradition draws its energy from alien threats to the American way of life and sanctions violent and exclusionary responses to them" [italics my emphasis] (Rogin 1984, 1).

\section{References}

Alfonso-Forero, A. M. 2011. Translating postcolonial pasts: Immigration and identity in the fiction of Bharati Mukherjee, Elizabeth Nunez and Jhumpa Lahiri. PhD diss., University of Miami, Florida.

Arnold, G. B. 2008. Conspiracy theory in film, television and politics. London: Greenwood Publishing Group.

Ashcroft, B., Griffiths, G. and Tiffin, H. 2003. The empire writes back: Theory and practice in post-colonial literatures. London and New York: Routledge.

Asl, M. P., Hull, S. P. and Abdullah, N. L. 2016. Nihilation of femininity in the battle of looks: A Sartrean reading of Jhumpa Lahiri's "A Temporary Matter". GEMA Online Journal of Language Studies 16(2): 123-139.

Aubeeluck, G. 2006. Indian Americans as native informants: Transnationalism in Bharati Mukherjee's "Jasmine", Jhumpa Lahiri's "The Namesake" and Kirin Narayan's "Love, Stars and All That". PhD diss., Illinois State University, Illinois.

Bhalla, T. A. 2008. Between history and identity: Reading the authentic in South Asian diasporic literature and community. $\mathrm{PhD}$ diss., The University of Michigan, Michigan. 
Bose, S. 2010. The family as the new collectivity of belonging in the fiction of Bharati Mukherjee and Jhumpa Lahiri. PhD diss., University of South Carolina, Columbia.

Cheung, F. and Dhingra, L. 2012. The inheritance of postcolonial loss, Asian American melancholia and strategies of compensation in Jhumpa Lahiri's "The Namesake". In Naming Jhumpa Lahiri: Canons and controversies, eds. Dhingra, L. and Cheung, F., 27-50. Plymouth, UK: Lexington Books.

Cohen, R. 1995. Rethinking "Babylon": Iconoclastic conceptions of the diasporic experience. Journal of Ethnic and Migration Studies 21(1): 5-18, https://doi.org/10.1080/1369183X.1995.9976469.

Das, S. K. 2013. Bengali diasporic culture: A study of the film adaptation of Jhumpa Lahiri's "The Namesake" (2003). The Criterion, an International Journal on English 4(2): 1-8.

Dhingra, L. 2012. Feminizing men? Moving beyond Asian American literary gender wars in Jhumpa Lahiri's fiction. In Naming Jhumpa Lahiri: Canons and controversies, eds. Dhingra, L. and Cheung, F., 135-155. Plymouth, UK: Lexington Books.

Dhingra, L. and Cheung, F., eds. 2012. Naming Jhumpa Lahiri: Canons and controversies. Plymouth, UK: Lexington Books.

Ferguson, R. A. and Hong, G. K. 2012. The sexual and racial contradictions of neoliberalism. Journal of Homosexuality 59(7): 1057-1064, https://doi.org/ 10.1080/00918369.2012.699848.

Foucault, M. 1995/1977. Discipline and punish, trans. Sheridan, A. New York: Vintage.

Ganguly, K. 2001. States of exception: Everyday life and postcolonial identity. Minneapolis, USA: University of Minnesota Press.

Grewal, I. 2005. Transnational America: Feminisms, diasporas, neoliberalisms. Durham and London: Duke University Press, https://doi.org/10.1215/9780822386544. 2003. Transnational America: Race, gender and citizenship after 9/11. Social Identities 9(4): 535-561, https://doi.org/10.1080/1350463032000174669.

Hale, J. 1996. Are lesbians women?. Hypatia 11(2): 94-121, https://doi.org/10.1111/ j.1527-2001.1996.tb00666.x.

Hall, S. 2007. Cultural identity and diaspora. In Transatlantic literary studies: A reader, eds. Susan Manning, S. and Taylor, A., 131-139. Edinburgh: Edinburgh University Press.

Hilaire, D. H. S. 2006. Immigrant West Indian families and their struggles with racism in America. Journal of Emotional Abuse 6(2-3): 47-60, https://doi.org/10.1300/ J135v06n02_04.

Hurley, J. S. 1997. After the Panopticon: Surveillance, scopophilia and the subject of the gaze. PhD diss., University of Virginia, Virginia.

Jespersen, J. L., Albrechtslund, A., Øhrstrøm, P., Hasle, P. and Albretsen, J. 2007. Surveillance, persuasion and Panopticon. In Persuasive technology, eds. de Kort, Y., IJsselsteijn, W., Midden, C., Eggen, B. and Fogg, B. J., 109-120. Berlin and Heidelberg: Springer, https://doi.org/10.1007/978-3-540-77006-0_15.

Jun, N. 2010. Toward an anarchist film theory: Reflections on the politics of cinema. Anarchist Developments in Cultural Studies, 1: 140-161. 
Kimmel, M. and Llewellyn, C. 2012. Homosexuality, gender nonconformity and the neoliberal state. Journal of Homosexuality 59(7): 1087-1094, https://doi.org/10.1080/00918369.2012.699865.

Lahiri, J. 2003. The Namesake. New York: Houghton Mifflin Company.

Lim, D. 2007. Identity is at heart of immigrant experience. Los Angeles Times, 9 March. Retrieved from http://articles.latimes.com/2007/mar/09/entertainment/etnamesake9 on 11 April 2016.

Liszka, J. J. 1999. Moral competence: An integrated approach to the study of ethics. New Jersey: Prentice Hall.

Mani, B. 2012. Cinema/photo/novel: Intertextual readings of "The Namesake". In Naming Jhumpa Lahiri: Canons and controversies, eds. Dhingra, L. and Cheung, F., 75-96. Plymouth, UK: Lexington Books.

McWhorter, L. 2013. Post-liberation feminism and practices of freedom. Foucault Studies 16: 54-73, https://doi.org/10.22439/fs.v0i16.4117.

Mohan, R. and Arora, M. K. 2013. Post-9/11 citizenship in diaspora literature and film adaptations: A case study of "The Namesake". New Academia 2(2): 33-40. . 2014. "Under western eyes" revisited: Feminist solidarity through anticapitalist struggles. Signs 40(1): 499-535.

Mohanty, C. T. 1984. Under western eyes: Feminist scholarship and colonial discourses. Boundary 2 12(3): 333-358, https://doi.org/10.2307/302821.

Mungwini, P. 2012. "Surveillance and cultural panopticism": Situating Foucault in African modernities. South African Journal of Philosophy 31(2): 340-353, https://doi.org/10.1080/02580136.2012.10751780.

Nagajothi, N. 2013. Transposal from fiction to motion picture: Crafting Jhumpa Lahiri's "The Namesake" on celluloid. Language in India 13(3): 540-552.

Obama, B. 2015. Remarks by the president at the national medals of the arts and humanities awards ceremony. Retrieved from https://www.whitehouse.gov/thepress-office/2015/09/11/remarks-president-national-medals-arts-and-humanitiesawards-ceremony on 16 November 2015.

Okihiro, G. Y. 2014. Margins and mainstreams: Asians in American history and culture. Seattle: University of Washington Press.

Ong, A. 2006. Mutations in citizenship. Theory, Culture and Society 23(2-3): 499-505, https://doi.org/10.1177/0263276406064831.

Pande, A. 2012. Diversities in the Indian diaspora: Nature, implications, responses. Diaspora Studies 5(1): 96-101, https://doi.org/10.1080/09739572.2013.764127.

Reddy, V. 2013. Jhumpa Lahiri's feminist cosmopolitics and the transnational beauty assemblage. Meridians: Feminism, Race, Transnationalism 11(2): 29-59, https://doi.org/10.2979/meridians.11.2.29.

Rogin, M. 1984. Kiss me deadly: Communism, motherhood and Cold War movies. Representations 6: 1-36.

Singh, A. and Schmidt, P. 2000. Postcolonial theory and the United States: Race, ethnicity and literature. Mississippi, USA: University Press of Mississippi.

Spivak, G. C. 1999. A critique of postcolonial reason. Massachusetts, USA: Harvard University Press.

1988. Can the subaltern speak?. In Marxism and the interpretation of culture, eds. Nelson, C. and Lawrence, G., 271-313. Illinois, USA: University of Illinois Press. 
United States Department of State, Office of the Historian. The Immigration Act of 1924 (The Johnson-Reed Act) [Data file]. Washington DC: United States Department of State. Retrieved from https://history.state.gov/milestones/1921-1936/immigrationact.

Vertovec, S. 1997. Three meanings of diaspora, exemplified among South Asian religions. Diaspora: A Journal of Transnational Studies 6(3): 1-37, https://doi.org/10.1353/dsp.1997.0010. 